\title{
Management of kyphoscoliosis patients with respiratory failure in the intensive care unit and during long term follow up
}

\author{
Nalan Adıgüzel 1*, Zuhal Karakurt', Gökay Güngör ${ }^{1}$, ÖzlemYazıcıoğlu Moçin ${ }^{1}$, Merih Balcı ${ }^{1}$, Cüneyt Saltürk ${ }^{1}$
} Feyza Kargın', Huriye Berk Takır', Ayşem Güven ${ }^{2}$ and Tülay Yarkın ${ }^{1}$

\begin{abstract}
Background: We aimed to evaluate the ICU management and long-term outcomes of kyphoscoliosis patients with respiratory failure.

Methods: A retrospective observational cohort study was performed in a respiratory ICU and outpatient clinic from 2002-2011. We enrolled all kyphoscoliosis patients admitted to the ICU and followed-up at regular intervals after discharge. Reasons for acute respiratory failure (ARF), ICU data, mortality, length of ICU stay and outpatient clinic data, non-invasive ventilation (NIV) device settings, and compliance were recorded. NIV failure in the ICU and the long term effect of NIV on pulmonary performance were analyzed.

Results: Sixty-two consecutive ICU kyphoscoliosis patients with ARF were enrolled in the study. NIV was initially applied to 55 patients, 11 (20\%) patients were intubated, and the majority had sepsis and septic shock $(p<0.001)$. Mortality in the ICU was $14.5 \%(n=9)$, reduced $\mathrm{pH}, \mathrm{IMV}$, and sepsis/septic shock were significantly higher in the non-survivors ( $p$ values $0.02,0.02,0.028,0.012$ respectively). Among 46 patients attending the outpatient clinic, 17 were lost to follow up and six were died. The six minute walk distance was significantly increased in the final follow up (306 m versus $419 \mathrm{~m}, \mathrm{p}<0.001$ ).

Conclusions: We strongly discourage the use of NIV in the case of septic shock in ICU kyphoscoliosis patients with ARF. Pulmonary performance improved with NIV during long term follow up.
\end{abstract}

Keywords: Kyphoscoliosis, Intensive care, Long-term noninvasive ventilation

\section{Background}

Kyphoscoliosis (KS) is characterized by diminished chest wall compliance and impaired respiratory mechanics, leading to progressive hypoventilation, hypercapnia and chronic respiratory failure (CRF) [1]. Acute exacerbations, particularly respiratory tract infections, rapidly worsen these patients' respiratory conditions and precipitate acute respiratory failure (ARF), which usually requires intensive care unit (ICU) hospitalization and either non-invasive or invasive mechanical ventilation [2].

Non-invasive, positive pressure ventilation (NIV) has become an accepted treatment option for CRF in chest

\footnotetext{
* Correspondence: nlnadiguzel@yahoo.com.tr

${ }^{1}$ Respiratory Intensive Care Unit, SB Süreyyapaşa Chest Diseases and Thoracic Surgery Teaching and Research Hospital, Istanbul, Turkey

Full list of author information is available at the end of the article
}

wall diseases [3]. Following the use of NIV in kyphoscoliosis patients with CRF, improvements in hypoventilation symptoms and a reduction in hospital readmissions have been shown [4-6]. However, ICU management and the long-term, post-ARF/ICU outcomes are rarely reported in these patients.

In the present study, we aimed to evaluate ICU management and long-term outcomes of patients with CRF due to kyphoscoliosis.

\section{Methods}

This study was conducted in a level III medical intensive care unit at a tertiary education hospital. The study was designed as a retrospective observational cohort study between August 2002 and May 2011. Patients were followed up for at least 12 months after discharge from 
ICU. The study was approved by the local ethical committee of the government teaching hospital.

\section{Patients}

Kyphoscoliosis patients who were admitted to the medical ICU with acute or acute-on-chronic hypercapnic respiratory failure were enrolled in the study. ARF was defined by the presence of acute breathing discomfort and arterial blood gases values $(\mathrm{ABG})$ : partial arterial oxygen pressure $\left(\mathrm{PaO}_{2}\right)<60 \mathrm{mmHg}$ on room air, or $\mathrm{PaO}_{2}$ over the fraction of inspired oxygen $\left(\mathrm{PaO}_{2} / \mathrm{FiO}_{2}\right)$ $<300$, partial arterial carbon dioxide pressure $\left(\mathrm{PaCO}_{2}\right)$ $\geq 45 \mathrm{mmHg}$ and $\mathrm{pH} \leq 7.35$ [7]. The reasons for ARF were recorded as cor pulmonale [8], sepsis/septic shock [9] due to pneumonia, lower respiratory tract infection, urinary tract and blood stream infection.

Sepsis was defined as proven or strongly suspected infection, and two of four criteria for systemic inflammatory response syndrome: 1 . A respiratory rate more than $20 /$ min or partial carbon dioxide pressure less than $32 \mathrm{mmHg}$; 2. A heart rate of more than 90 beats/min; 3. A temperature more than $38.3^{\circ} \mathrm{C}$ or less than $36.0^{\circ} \mathrm{C}$; 4 . A white blood cell count of more than 12,000 cells/ $\mu$ l or less than 4,000 cells $/ \mu \mathrm{l}$, or more than $10 \%$ immature cells [9]. Septic shock was defined as sepsis-induced hypotension (systolic blood pressure of less than $90 \mathrm{mmHg}$ or a reduction of more than $40 \mathrm{mmHg}$ from baseline in absence of other causes of hypotension), and patients requiring vasopressor to maintain a mean arterial pressure of more than $70 \mathrm{mmHg}$ despite adequate fluid resuscitation [9].

Pneumonia was defined as the acute onset of symptoms suggestive of a lower respiratory tract infection and radiographical evidence of a new infiltrate [10]. The presence of a nosocomial infection on admission to ICU was recorded, and all patients were treated according to guidelines [11].

\section{Assessment of mechanical ventilations Non-invasive mechanical ventilation}

NIV was delivered in pressure assist-control mode with ICU mechanical ventilators via a double tube circuit with a full-face mask. Pressure support (PS) was initially set at $10 \mathrm{cmH}_{2} \mathrm{O}$ and gradually increased to a maximum of 30 $\mathrm{cmH}_{2} \mathrm{O}$ until the exhaled tidal volume was $8-10 \mathrm{ml} / \mathrm{kg}$ and guided by patient tolerance. Positive end-expiratory pressure (PEEP) was set at $5 \mathrm{cmH}_{2} \mathrm{O}$ and raised if needed to treat hypoxemia, or lowered to enhance patient comfort. The fraction of inspired oxygen $\left(\mathrm{FiO}_{2}\right)$ was adjusted to keep oxygen saturation $\left(\mathrm{SaO}_{2}\right)$ at $90 \%$. NIV was applied intermittently for periods of 1 to $4 \mathrm{~h}$ and initial ABG samples were obtained at the end of first hour. The duration of each session was determined by improvement in ABG levels, the level of consciousness, and patient compliance. The level of consciousness was assessed by the Glasgow coma scale (GCS) [12].

\section{Intubation and NIV failure criteria}

NIV was considered to have failed if at least one of the following criteria for endotracheal intubation (ET) occurred: 1. Cardiac arrest or severe hemodynamic instability (mean arterial pressure $<65 \mathrm{mmHg}$ or the need for vasoactive agents); 2. Respiratory arrest; 3. Mask intolerance with agitation requiring sedation; 4 . Severe difficulty clearing secretions; 5. Failure of gas exchange within the first 1 to $4 \mathrm{~h}$ of NIV therapy; 6 . Lack of improvement in consciousness $[3,13]$.

\section{Invasive mechanical ventilation}

Invasive mechanical ventilation (IMV) was delivered in pressure assist-control ventilation (PCV) mode and PS was initially set at $10 \mathrm{cmH}_{2} \mathrm{O}$ and then gradually increased to a maximum of $30 \mathrm{cmH}_{2} \mathrm{O}$ until the exhaled tidal volume was $8-10 \mathrm{ml} / \mathrm{kg}$, as with the NIV settings. An intermittent sedation protocol was applied with midazolam according to Richmond agitation-sedation scale [14]. After cessation of sedation, patients were evaluated for weaning. When patients were conscious and hemodynamically stabile, a T-tube trial was performed, and after 30 minutes patients were extubated according to our weaning protocol. If there was still a demand for mechanical ventilation after weaning due to hypercapnia we preferred to continue with NIV. We prescribed domiciliary NIV devices according to home mechanical ventilation guidelines after a good response was achieved by NIV during the ICU stay [15]. All patients received education from a specialized NIV nurse for using these NIV devices prior to discharge.

\section{Follow up}

Patients were evaluated for the efficacy of NIV and treatment adherence in an outpatient clinic one month after ICU discharge, and then at 3-6 months intervals. Treatment efficacy was assessed by clinical status and ABG values. IPAP (inspiratory positive airway pressure) and EPAP (expiratory positive airway pressure) values of NIV devices were recorded. The physiological and functional parameters were compared with IPAP-EPAP and IPAPEPAP/weight as defined by Budweisser et al. [16]. Objective NIV usage was also measured by a specialized NIV nurse at every outpatient clinic visit by checking the built-in time counter of the NIV device. The NIV compliance was defined by the use of NIV more than four hours a day or $>20$ hour a week [15].

\section{Data collections}

We recorded patients' age, gender, body mass index (BMI, $\mathrm{kg} / \mathrm{m}^{2}$ ), Glasgow coma scale (GCS) [8], acute 
physiology and chronic health evaluation (APACHE) II scores [17], ABG values on admission to ICU, comorbid diseases, causes of ARF, presence of oxygen therapy, NIV or IMV (tracheostomy) use for long-term home therapy prior to ICU stay, ICU respiratory management (need for NIV, ventilation mode and duration, need for and duration of tracheal intubation, tracheostomy), status on ICU discharge (deceased or alive) and respiratory status/management on ICU discharge (spontaneous breathing, NIV, tracheostomy).

Arm span (largest distance across the middle fingers when the arms are stretched horizontally sideways) was used as the height of KF patients for BMI and spirometry measurements [18]. The six-minute walk test (6-MWT) was performed on eligible patients in the follow up period, and the 6-minute walk distance (6-MWD) was recorded (in meters) [19].

We also recorded pulmonary function tests, ABG values at the first and last outpatient clinic admission, treatment compliance, and whether the patient was deceased or surviving. The total number of hospital and ICU readmissions with additional ARF episodes were obtained from the hospital electronic database.

\section{Statistical analysis}

A descriptive analysis was used for patients' demographics, ICU data. Survivors versus non-survivors and NIV success versus NIV failure were compared by the Mann Whitney $U$ test for non-parametric continuous variables, and the $\chi^{2}$ test was used for dichotomous variable. The relationship of IPAP-EPAP/weight with 6-MWD and $\mathrm{PaCO}_{2}$ and spirometry results were evaluated with the Spearman's correlations test. The Wilcoxon two related sample test was used for comparison of the first and last ABG and spirometry test results during the follow up period. Median and interquartile ratio was used for continuous variables. Count and percentage were used when applicable. A p value $<0.05$ was accepted as statistically significant.

\section{Results}

\section{Patients}

During the study period, 62 kyphoscoliosis patients (29 female) with ARF were included. Thirty-nine patients were admitted from the ward, 17 from the emergency department, and six from another ICU (Table 1). The reasons for kyphoscoliosis were idiopathic $(n=42$, $67.7 \%)$, post-rachitic $(n=9,14.5 \%)$, rheumatologic disease $(n=7,11.4 \%)$, post-poliomyelitis $(n=2,3.2 \%)$ and post-traumatic $(n=2,3.2 \%)$. The median (interquartile range) age was 52 (45-65) years, and median BMI was $23(21-27) \mathrm{kg} / \mathrm{m}^{2}$. All patients were hypercapnic and 55 (88.7\%) patients were both hypercapnic and hypoxemic. The reasons for ICU admission were: two patients (3.3\%) had a home NIV device problem, 26 (41.9\%) had
Table 1 Patient's comorbidity and ICU data

\begin{tabular}{lc}
\hline Pre ICU localization, $\mathbf{n}(\%)$ & \\
\hline ward & $39(62.9)$ \\
Emergency department & $17(27.4)$ \\
Other ICU & $6(9.7)$ \\
Comorbid diseases, $\mathbf{N}$ (\%) & $46(75.4)$ \\
Diabetes mellitus & $4(6.6)$ \\
Hypertension & $20(32.3)$ \\
Congestive heart failure & $14(22.6)$ \\
Renal failure & $1(1.6)$ \\
Domiciliary oxygen therapy, N (\%) & $15(24.6)$ \\
Domiciliary ventilator therapy, N (\%) & $4(6.5)$ \\
APACHE II on ICU admission, median(IQR) & $15(12-19)$ \\
Arterial blood gases on admission, median(IQR) & \\
$\mathrm{pH}^{\mathrm{PaCO}}{ }_{2}$, mmHg & $7.34(7.29-7.40)$ \\
$\mathrm{PaO}_{2}$, mmHg & $69.5(61.0-81.7)$ \\
$\mathrm{HCO}_{3}$, mmol/l & $70.9(54.3-84.2)$ \\
$\mathrm{PaO}_{2} / \mathrm{FiO}$ &
\end{tabular}

ICU, intensive care unit; APACHE, acute physiology and chronic health evaluation; $\mathrm{PaO}_{2}$, partial arterial oxygen pressure; $\mathrm{PaCO}_{2}$, partial arterial carbondioxide pressure; $\mathrm{FiO}_{2}$, fraction of inspired oxygen; $\mathrm{HCO}_{3}$, hydrogen bicarbonate; IQR, interquartile ratio.

cor pulmonale, 26 (41.9\%) had severe sepsis, and eight (12.9\%) had septic shock. Pneumonia was diagnosed in 17 patients, seven of which had septic shock. Other reasons for sepsis were urinary tract infection $(n=3)$, lower respiratory tract infection $(n=13)$, and blood stream infection $(n=1)$. Patients' comorbidity and domiciliary devices (NIV or oxygen), and ABGs values on admission to the ICU are shown in Table 1.

\section{Assessment of mechanical ventilation}

In the study period, seven patients (11.4\%) initially received IMV (two via tracheostomy) and 55 (88.6\%) patients received NIV. Eleven patients (17.7\%) were intubated after initial NIV application. Two patients died during NIV therapy due to acute myocardial infarction. The overall NIV success rate was 76.4\% (42/55). Mechanical ventilation and ICU outcomes are shown in Figure 1. Five NIV failures and two patients who were initially intubated died because of sepsis with a resistant pathogen.

All intubated and tracheostomized $(n=2)$ patients were ventilated in pressure assist-control mode with the median (IQR) PS $17(10-19) \mathrm{cmH}_{2} \mathrm{O}$ to get tidal volume $8-10 \mathrm{ml} / \mathrm{kg}$ and PEEP to $6(5-6) \mathrm{cmH}_{2} \mathrm{O}$. During NIV applications, the median PS was 15 (10-19) $\mathrm{cmH}_{2} \mathrm{O}$ and PEEP was 6 (5-6) $\mathrm{cm} \mathrm{H}_{2} \mathrm{O}$; the median NIV hours per day were 11.0 (9.2-12.9). None of the patients had pneumothorax. The median length of stay in the ICU was 8 (5-14) days. The overall ICU mortality was $14.5 \%$ 
Mechanical ventilations and intensive care unit outcomes

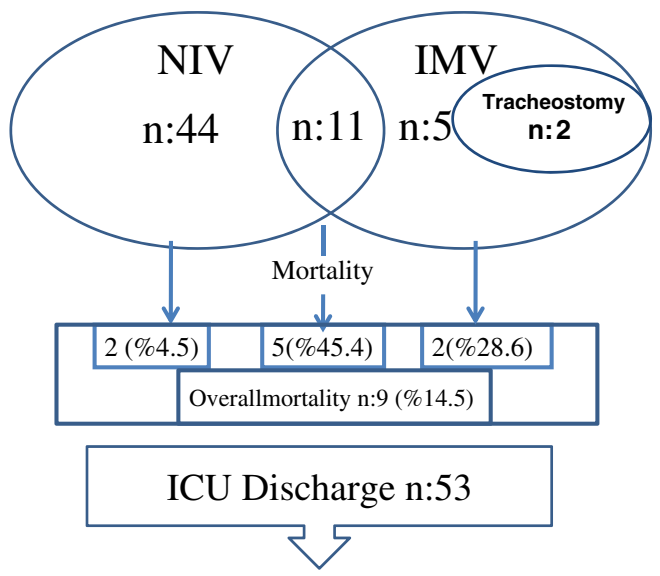

Figure 1 Mechanical ventilation outcomes of kyphoscoliosis patients in intensive care unit.

(see Figure 1 for mortality relative to mechanical ventilation support). Five patients were tracheostomized due to weaning failure. Surviving and non-surviving patients were further compared according to gender, age, initial ABGs, mechanical ventilation (IMV or NIV), and the presence of sepsis and septic shock on admission to the ICU (Table 2). The non-surviving kyphoscoliosis patients had significantly lower $\mathrm{pH}$ values, a higher rate of IMV, and a higher rate of sepsis and septic shock (Table 2) ( $\mathrm{p}$ values were $0.02,0.02,0.028,0.012$ respectively). Both groups had a statistically similar length of stay in the ICU $(\mathrm{p}=0.40)$ (Table 2).

Table 2 A comparison patient data of survivors versus non-survivors of kyphoscoliosis patients in the ICU

\begin{tabular}{|c|c|c|c|}
\hline & $\begin{array}{l}\text { Survivors, } \\
\mathrm{n}=53\end{array}$ & $\begin{array}{l}\text { Non-survivors, } \\
n=9\end{array}$ & $p$ \\
\hline Gender, male/female & $29 / 24$ & $4 / 5$ & 0.72 \\
\hline Age, years & $51(45-64)$ & $62(45-70)$ & 0.49 \\
\hline APACHE II, median(IQR) & $15(12-19)$ & $16(14-19)$ & 0.26 \\
\hline $\begin{array}{l}\text { pH on admission, } \\
\text { median(IQR) }\end{array}$ & $7.37(7.30-7.40)$ & $7.29(7.28-7.31)$ & 0.02 \\
\hline $\begin{array}{l}\mathrm{PaCO}_{2} \text { on admission, } \\
\text { median(IQR) }\end{array}$ & $69.0(60.1-80.8)$ & $80.0(73.0-83.0)$ & 0.10 \\
\hline $\mathrm{PaO}_{2} / \mathrm{FiO}_{2}$, median(IQR) & $195(147-275)$ & $161(145-189)$ & 0.08 \\
\hline IMV, n (\%) & $11(20.8)$ & $7(77.8)$ & 0.02 \\
\hline NIV, n (\%) & $48(90.6)$ & $7(77.8)$ & 0.26 \\
\hline Sepsis on admission, n (\%) & $19(35.8)$ & $7(77.8)$ & 0.028 \\
\hline $\begin{array}{l}\text { Septic shock on admission, } \\
n(\%)\end{array}$ & $4(7.5)$ & $4(44.4)$ & 0.012 \\
\hline Length of stay in ICU, day & $8(5-14)$ & $13(8-18)$ & 0.40 \\
\hline
\end{tabular}

$\mathrm{ICU}$, intensive care unit; IQR, interquartile ratio; APACHE, acute physiology and chronic health evaluation; $\mathrm{PaCO}_{2}$, partial arterial carbondioxide pressure; $\mathrm{PaO}_{2}$, partial arterial oxygen pressure; $\mathrm{FiO}_{2}$, fraction of inspired oxygen; IMV, invasive mechanical ventilation; NIV, non-invasive mechanical ventilation.
In the 55 patients who received NIV ABGs values were obtained on admission to the ICU and after the first hour of NIV, to assess NIV response (summarized in Table 3). NIV failure patients had significantly lower $\mathrm{pH}$ values at admission and after the first hour of NIV ( $\mathrm{p}<0.005, \mathrm{p}<0.026$ respectively, Table 3$)$.

There were 13 patients where NIV failed; 11 were intubated for IMV and two died due to myocardial infarction during NIV. A significantly higher rate of sepsis/septic shock was found in the NIV failure patients $(\mathrm{n}=11 / 13)$ than in the NIV success patients $(\mathrm{n}=16 / 42)$ $(\mathrm{p}<0.004, \mathrm{X}$ square, fisher exact test, Figure 2).

\section{Follow up period}

Fifty-three patients were discharged from ICU (18 to home, 35 to the the ward). Two patients died in the ward and overall hospital mortality was $17.7 \%(n=11)$. The long-term follow up outcomes are summarized in Figure 3.

After the initial one-month follow up at the outpatient clinic, 29 patients were followed-up for longer than 12 months. The median (IQR) follow up was 48 months (24-65) and NIV compliance rate was $79.3 \%$. The rehospitalization of eight of these 29 patients was recorded during the follow up period and they were re-admitted 19 times for pneumonia $(\mathrm{n}=8)$, pulmonary embolism $(\mathrm{n}=3)$, acute cor pulmonale $(\mathrm{n}=5)$, pneumothorax $(\mathrm{n}=1)$, and NIV device impairment $(\mathrm{n}=2)$. The initial

Table 3 Arterial blood gases values on admission to the ICU and after the first hour of NIV in patients with NIV success and failure

\begin{tabular}{llll}
\hline & $\begin{array}{l}\text { NIV success, } \\
\mathbf{n = 4 4}\end{array}$ & $\begin{array}{l}\text { NIV failure, } \\
\mathbf{n = 1 1}\end{array}$ & $\mathbf{p}$ \\
\hline $\begin{array}{l}\text { APACHE II score, } \\
\text { median(IQR) }\end{array}$ & $14(12-16)$ & $20(17-23)$ & 0.001 \\
$\begin{array}{l}\text { GCS, median(IQR) } \\
\begin{array}{l}\text { Respiratory } \\
\text { rate, median(IQR) [bpm] }\end{array}\end{array}$ & $15(14-15)$ & $14(10-15)$ & 0.002 \\
& $25(22-31)$ & $26(19-37)$ & 0.58
\end{tabular}

$A B G$ s on admission to the ICU, median(IQR)

$\begin{array}{llll}\mathrm{pH} & 7.37(7.30-4.40) & 7.28(7.26-7.32) & 0.005 \\ \mathrm{paCO}_{2}, \mathrm{mmHg} & 69.0(61.2-78.6) & 81.6(72.5-93.2) & 0.015 \\ \mathrm{PaO}_{2} / \mathrm{FiO}_{2} & 201(149-274) & 161(137-191) & 0.12 \\ \mathrm{HCO}_{3}, \mathrm{mmol} & 37.7(33.2-41.2) & 38.9(33.1-41.1) & 0.74\end{array}$

First control ABGs after NIV, median(IQR)

$\begin{array}{llll}\mathrm{pH} & 7.38(7.34-7.42) & 7.29(2.25-7.40) & 0.026\end{array}$

$\begin{array}{llll}\mathrm{paCO}_{2}, \mathrm{mmHg} & 62.9(55.6-77.7) & 77.0(57.8-90.6) & 0.07\end{array}$

$\mathrm{PaO}_{2} / \mathrm{FiO}_{2} \quad 234(202-293) \quad 193(137-219) \quad 0.015$

$\begin{array}{llll}\mathrm{HCO}_{3}, \mathrm{mmol} & 35.4(33.0-40.0) & 36.4(32.5-39.8) & 0.74\end{array}$

$A B G$, arterial blood gas; ICU, intensive care unit; IQR, interquartile ratio; APACHE, acute physiology and chronic health evaluation; GCS, Glascow Coma Scale; bpm, breaths per minute; $\mathrm{PaCO}_{2}$, partial arterial carbondioxide pressure; $\mathrm{PaO}_{2}$, partial arterial oxygen pressure; $\mathrm{FiO}_{2}$, fraction of inspired oxygen; $\mathrm{HCO}_{3}$, hydrogen bicarbonate. 


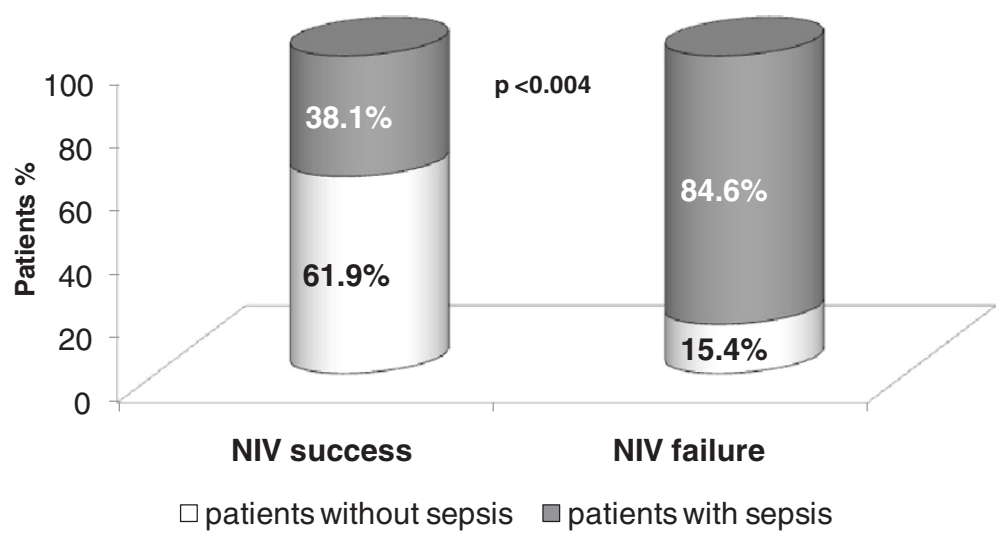

Figure 2 Sepsis in patients with non-invasive ventilation success and failure.

and final pulmonary function test results (ABG, spirometry and 6-MWD) are summarized in Table 4.

Median IPAP and EPAP of NIV device were 20 (18-25) $\mathrm{cmH}_{2} \mathrm{O}$, and 5 (5-6) $\mathrm{cm} \mathrm{H}_{2} \mathrm{O}$ respectively in initial follow up. The median IPAP-EPAP difference was 15 (12-19) $\mathrm{cmH}_{2} \mathrm{O}$, and the median IPAP-EPAP/weight ratio was 0.26 (0.16-0.31). The relationship between IPAP-EPAP/ weight with 6-MWD, $\mathrm{PaCO}_{2}$ and spirometry results were evaluated with Spearman's correlations test. IPAP-EPAP/weight ratio was significantly positively correlated with 6-MWD $(r=0.49, \mathrm{p}=0.029)$ but no correlation was found between $\mathrm{PaCO}_{2}$ and spirometry test results.

\section{Discussion}

In the present study we evaluated acute and chronic respiratory failure management and outcomes in a substantial population of the rare disease kyphoscoliosis.
The success rate of applying non-invasive mechanical ventilation in kyphoscoliosis patients with acute respiratory failure was found to be $76.4 \%$ in our ICU. The rate of sepsis in patients with NIV failure was higher than in patients with NIV success. The mortality rate was higher in patients in ICU with NIV failure, using IMV, and with septic shock. The prescription rates of long-term mechanical ventilation and NIV compliance were $70.6 \%$ and 79.3\% respectively. The six-minute walk distance increased significantly after long-term NIV.

There are currently no reports on the reasons why kyphoscoliosis patients with acute respiratory failure require ICU admission and mechanical ventilation. However, pneumonia and cor pulmonale are seen in one third of hospitalized chronic obstructive pulmonary disease (COPD) patients with NIV [20]. The primary reasons for ARF in our kyphoscoliosis patients were cor pulmonale and sepsis. Pneumonia was the primary cause

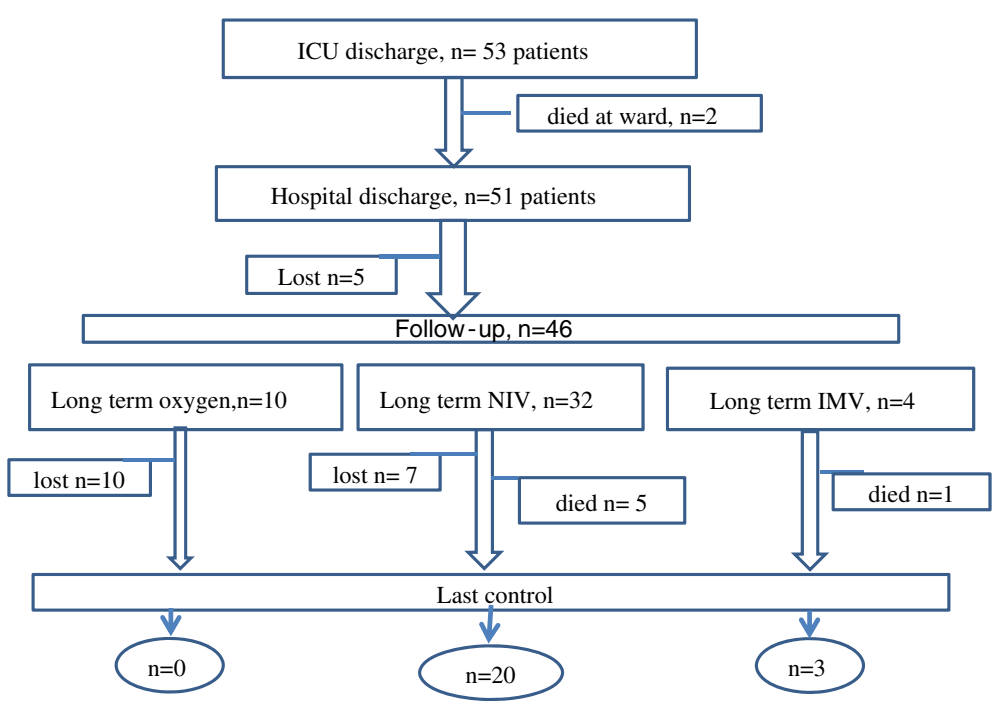

Figure 3 Follow-up outcomes of kyphoscoliosis patients. 


\begin{tabular}{|c|c|c|c|}
\hline & $\begin{array}{l}\text { First control } \\
\text { Median (IQR) }\end{array}$ & $\begin{array}{l}\text { Last control } \\
\text { Median (IQR) }\end{array}$ & $p^{*}$ \\
\hline $\mathrm{pH}$ & $7.43(7.41-7.44)$ & $7.43(7.40-7.46)$ & 0.001 \\
\hline $\mathrm{PaCO}_{2}$ & $47.7(44.0-53.9)$ & $50.4(46.3-54.0)$ & 0.18 \\
\hline $\mathrm{PaO}_{2} / \mathrm{FiO}_{2}$ & $300(275-332)$ & $304(269-328)$ & 0.75 \\
\hline $\mathrm{HCO}_{3} \mathrm{mmol}$ & $31.0(28.6-35.3)$ & $32.1(30.1-34.8)$ & 0.44 \\
\hline $\mathrm{FEV}_{1}, \mathrm{ml}$ & $670(550-860)$ & 840 (520-940) & 0.46 \\
\hline $\mathrm{FEV}_{1} \%$ & $34(18-40)$ & $35(21-44)$ & 0.50 \\
\hline $\mathrm{FVC}, \mathrm{ml}$ & $830(740-1100)$ & $955(640-1160)$ & 0.35 \\
\hline FVC\% & $32(21-38)$ & $34(22-41)$ & 0.50 \\
\hline $\mathrm{FEV}_{1} / \mathrm{FVC}$ & $82(78-89)$ & 88 (81-91) & 0.87 \\
\hline 6-MWD, m & $306(220-405)$ & $419(348-462)$ & 0.001 \\
\hline
\end{tabular}

Wilcoxon two related sample test. $\mathrm{PaCO}_{2}$, partial arterial carbondioxide pressure; $\mathrm{PaO}_{2}$, partial arterial oxygen pressure; $\mathrm{FiO}_{2}$, fraction of inspired oxygen; $\mathrm{HCO}_{3}$, Hydrogen bicarbonate, $\mathrm{FEV}_{1}$, forced expiratory volume in 1 second; FVC, forced vital capacity; 6-MWD, 6 minute walking distance.

of sepsis. We found that NIV failure patients had a higher mortality rate than initially intubated patients. This may be related to delayed intubation due to a minimal improvement of ABG values after the first hour of NIV treatment. NIV success patients had a 4.5 percent mortality rate (Figure 1).

NIV failure risk factors in COPD are well studied and defined with guidelines [3,21-23]. Confalonieri and coworkers presented a chart where NIV failure in patients with COPD was in a red zone [23]. Patients in the red zone had a respiratory rate $\geq 30, \mathrm{GCS} \leq 11, \mathrm{pH}<7.25$, and an APACHE II score $\geq 29$ on admission to ICU. These were accepted as the most important parameters for NIV failure criteria [23]. Although the patients presented here were not diagnosed with COPD, NIV failure kyphoscoliosis patients in the ICU had a significantly higher APACHE II score and respiratory rate, but lower GCS and $\mathrm{pH}$ values (20 versus 14 score; 26 versus 25 breath /min, 14 versus 15 score; 7.28 versus 7.37 , respectively). These results were not as severe as those observed in NIV failure due to COPD, as described [3,21-23].

\section{Follow up}

NIV compliance for long-term usage varies according to the underlying diseases, such as COPD, obesity hypoventilation, neuromuscular disease and kyphoscoliosis. The NIV compliance rate of kyphoscoliosis patients is currently reported to be between 79 and $90 \%$ [24-26]. In the present study, 29 kyphoscoliosis patients with NIV were tightly compliant to the outpatient clinic controls. Patients without a NIV device $(n=10)$ did not attend the outpatient clinic. The NIV compliance rate ( $>4$ hours a day) was $79.3 \%$.
Volume or pressure cycled NIV settings have previously been used for long-term home therapy and both have showed similar results in various studies [3,27-29]. We used pressure cycled NIV devices. Budweiser and coworkers showed that PS greater than $15 \mathrm{cmH}_{2} \mathrm{O}$ improved the decrease in $\mathrm{PaCO}_{2}$ for long-term follow up in patients with restrictive thoracic diseases [16]. They concluded that IPAP-EPAP/weight ratio correlated with the $\mathrm{PaCO}_{2}$ decrease at the initial follow up after hospital discharge with long-term NIV [16]. However we did not find any correlation between $\triangle \mathrm{PaCO}_{2}$ and IPAP-EPAP/ weight and the initial outpatient clinic data (pulmonary function, 6-MWD and ABG values). IPAP-EPAP/weight ratio was significantly correlated with 6-MWD but not with the other parameters. A recent review which evaluated 41 studies published over an 18 year period, looked at the physiological effects of NIV on work-of-breathing (WOB), pressure-support of $15 \mathrm{cmH}_{2} \mathrm{O}$ and a PEEP of $5 \mathrm{cmH}_{2} \mathrm{O}$, and showed reduced WOB in patients primarily with chronic pulmonary disease including kyphoscoliosis [30]. In the present study IPAP was, in most cases, set greater than $20 \mathrm{cmH}_{2} \mathrm{O}$, and EPAP was set as $5 \mathrm{cmH}_{2} \mathrm{O}$, similar to previous studies $[16,30]$.

The mortality rates of kyphoscoliosis patients with longterm domiciliary NIV therapy have been reported as 9.5\% over two years, and $21 \%$ over five years [26,28]. In the present study the mortality rate was $20.7 \%$ over 4 years.

There are some limitations in our study. Firstly, we designed it retrospectively and in one center. Secondly, the physiological respiratory muscle function tests (ie, diaphragm functions) and the measurement of the degree of spinal curvature were not done. The use of the degree of curvature and the severity of respiratory failure relation is controversial [31,32]. Thirdly, the ICU mortality risk analysis was not done due to small number of non-surviving patients.

\section{Conclusion}

Kyphoscoliosis patients with respiratory failure due to pump failure have a mainly good response to NIV. However, in specific disease groups and the presence of sepsis/ septic shock NIV failure may result. For this reason we strongly discourage the use of NIV in the case of septic shock. Although this is a single center study and we cannot generalize the results for all patients, this study may help to make a decision on the clinical management of kyphoscoliosis patients with ARF in the ICU. Pulmonary function tests and 6-MWD of kyphoscoliosis patients can improve with nearly $15 \mathrm{cmH}_{2} \mathrm{O}$ pressure support with pressure cycled NIV devices during long term follow up.

\section{Competing interests}

As the authors of "Management of kyphoscoliosis patients with respiratory failure in the intensive care unit and during long-term follow up" we declare that we 
have no competing interests that might be related to the contents of the manuscript.

\section{Acknowledgments}

The authors thank the physiotherapist R. Evin for helping to perform 6minute walk test and the nurses S. Solmaz and R. Sancar for their help in the outpatient clinic

\section{Author details}

${ }^{1}$ Respiratory Intensive Care Unit, SB Süreyyapaşa Chest Diseases and Thoracic Surgery Teaching and Research Hospital, Istanbul, Turkey. ${ }^{2}$ Pulmonary Department, Erzurum Teaching and Research Hospital, Erzurum, Turkey.

Received: 29 June 2012 Accepted: 9 August 2012

Published: 21 September 2012

\section{References}

1. Bergofsky EH: Respiratory failure in disorders of the thoracic cage. Am Rev Respir Dis 1979, 119:643-669.

2. Banfi P, Redolfi S, Robert D: Home treatment of infection-related acute respiratory failure in kyphoscoliotic patients on long-term mechanical ventilation. Respir Care 2007, 52:713-719.

3. Clinical indications for noninvasive positive pressure ventilation in chronic respiratory failure due to restrictive lung disease, COPD, and nocturnal hypoventilation--a consensus conference report. Chest 1999, 116:521-534.

4. Gonzalez C, Ferris G, Diaz J, et al: Kyphoscoliotic ventilatory insufficiency: effects of long-term intermittent positive-pressure ventilation. Chest 2003, 124:857-862.

5. Hill NS, Eveloff SE, Carlisle CC, Goff SG: Efficacy of nocturnal nasal ventilation in patients with restrictive thoracic disease. Am Rev Respir Dis 1992, 145(2 Pt 1):365-371.

6. Masa Jiménez JF, Sánchez De Cos Escuin J, Disdier Vicente C, Hernández Valle M, Fuentes Otero F: Nasal intermittent positive pressure ventilation. Analysis of its withdrawal. Chest 1995, 107:382-388.

7. British Thoracic Society Standards of Care Committee: Non-invasive ventilation in acute respiratory failure. Thorax 2002, 57:192-211.

8. Willius FA: Cor Pulmonale. Can Med Assoc J 1946, 54:42-46.

9. Bone RC, Balk RA, Cerra FB, Dellinger RP, Fein AM, Knaus WA, Schein RM, Sibbald WJ: Definitions for sepsis and organ failure and guidelines for the use of innovative therapies in sepsis. The ACCP/SCCM Consensus Conference Committee. American College of Chest Physicians/Society of Critical Care Medicine. Chest 1992, 101:1644-1655.

10. Niederman MS, Mandell LA, Anzueto A, Bass JB, Broughton WA, Campbell GD, Dean N, File T, Fine MJ, Gross PA, Martinez F, Marrie TJ, Plouffe JF, Ramirez J, Sarosi GA, Torres A, Wilson R, Yu VL: American Thoracic Society. Guidelines for the management of adults with community-acquired pneumonia. Diagnosis, assessment of severity, antimicrobial therapy, and prevention. Am J Respir Crit Care Med 2001, 163:1730-1754.

11. American Thoracic Society; Infectious Diseases Society of America: Guidelines for the management of adults with hospital-acquired, ventilator-associated, and healthcare-associated pneumonia. Am J Respir Crit Care Med 2005, 171:388-416.

12. Winston SR: Preliminary communication: EMT and the Glasgow [correction of Glascow] Coma Scale. J lowa Med Soc 1979, 69:393-398.

13. Mehta S, Hill NS: Noninvasive ventilation in acute respiratory failure. Respir Care Clin N Am 1996, 2:267-292.

14. Sessler CN, Gosnell MS, Grap MJ, Brophy GM, O'Neal PV, Keane KA, Tesoro EP, Elswick RK: The Richmond Agitation-Sedation Scale: validity and reliability in adult intensive care unit patients. Am J RespirCrit Care Med 2002, 166:1338-1344.

15. Make BJ, Hill NS, Goldberg Al, Bach JR, Criner GJ, Dunne PE, Gilmartin ME, Heffner JE, Kacmarek R, Keens TG, McInturff S, O'Donohue WJ Jr, Oppenheimer EA, Robert D: Mechanical ventilation beyond the intensive care unit, Report of a consensus conference of the American College of Chest Physicians. Chest 1998, 113(5 Suppl):289-344.

16. Budweiser S, Heinemann F, Fischer W, Dobroschke J, Wild PJ, Pfeifer M: Impact of ventilation parameters and duration of ventilator use on noninvasive home ventilation in restrictive thoracic disorders. Respiration 2006, 73:488-494.
17. Knaus WA, Draper EA, Wagner DP, Zimmerman JE: APACHE II: a severity of disease classification system. Crit Care Med 1985, 13:818-829.

18. Miller MR, Hankinson J, Brusasco V, Burgos F, Casaburi R, Coates A, Crapo R, Enright $P$, van der Grinten CP, Gustafsson P, Jensen R, Johnson DC, MacIntyre N, McKay R, Navajas D, Pedersen OF, Pellegrino R, Viegi G, Wanger J, ATS/ERS Task Force: Standardization of spirometry. Eur Respir J 2005, 26:319-338.

19. Committee ATSon Proficiency Standards for Clinical Pulmonary Function Laboratories: ATS statement: guidelines for the six-minute walk test. Am J Respir Crit Care Med 2002, 166:111-117.

20. Chu CM, Chan VL, Lin AW, Wong IW, Leung WS, Lai CK: Readmission rates and life threatening events in COPD survivors treated with non-invasive ventilation for acute hypercapnic respiratory failure. Thorax 2004, 59:1020-1025

21. Organized jointly by the American Thoracic Society: the European Respiratory Society, the European Society of Intensive Care Medicine, and the Société de Réanimation de Langue Française, and approved by ATS Board of Directors, December 2000. International Consensus Conferences in Intensive Care Medicine: noninvasive positive pressure ventilation in acute Respiratory failure. Am J Respir Crit Care Med 2001, 163:283-291.

22. Ambrosino N, Foglio K, Rubini F, Clini E, Nava S, Vitacca M: Non-invasive mechanical ventilation in acute respiratory failure due to chronic obstructive pulmonary disease: correlates for success. Thorax 1995, 50:755-757.

23. Confalonieri M, Garuti G, Cattaruzza MS, Osborn JF, Antonelli M, Conti G, Kodric M, Resta O, Marchese S, Gregoretti C, Rossi A: Italian noninvasive positive pressure ventilation (NPPV) study group. A chart of failure risk for noninvasive ventilation in patients with COPD exacerbation. Eur Respir J 2005, 25:348-355.

24. Leger P, Bedicam JM, Cornette A, Reybet-Degat O, Langevin B, Polu JM, Jeannin L, Robert D: Nasal intermittent positive pressure ventilation. Long-term follow-up in patients with severe chronic respiratory insufficiency. Chest 1994, 105:100-105.

25. Simonds AK, Elliott MW: Outcome of domiciliary nasal intermittent positive pressure ventilation in restrictive and obstructive disorders. Thorax 1995, 50:604-609.

26. Janssens JP, Derivaz S, Breitenstein E, De Muralt B, Fitting JW, Chevrolet JC, Rochat T: Changing patterns in long-term noninvasive ventilation: a 7year prospective study in the Geneva Lake area. Chest 2003, 123:67-79.

27. Hill NS, Eveloff SE, Carlisle CC: Efficacy of nocturnal ventilation in patients with restrictive thoracic disease. Am Rev Respir Dis 1992, 145:365-371.

28. Leger P: Noninvasive positive pressure ventilation at home. Respir Care 1994, 39:501-510.

29. Goldstein RS: Hypoventilation: neuromuscular and chest wall disorders. Clin Chest Med 1992, 13:507-521.

30. Kallet RH, Diaz JV: The physiologic effects of noninvasive ventilation. Respir Care 2009, 54:102-115.

31. Muirhead A, Conner A: The assessment of lung function in children with scoliosis. J Bone Joint Surg Br 1985, 67:699-702.

32. Smyth RJ, Chapman KR, Wright TA, Crawford JS, Rebuck AS: Pulmonary function in adolescents with mild idiopathic scoliosis. Thorax 1984, 39:901-904.

doi:10.1186/2049-6958-7-30

Cite this article as: Adıgüzel et al:: Management of kyphoscoliosis patients with respiratory failure in the intensive care unit and during long term follow up. Multidisciplinary Respiratory Medicine 2012 7:30. 